\title{
Control of the meiotic cell division program in plants
}

\author{
Erik Wijnker $\cdot$ Arp Schnittger
}

Received: 21 May 2013/Accepted: 23 June 2013/Published online: 14 July 2013

(C) The Author(s) 2013. This article is published with open access at Springerlink.com

\begin{abstract}
While the question of why organisms reproduce sexually is still a matter of controversy, it is clear that the foundation of sexual reproduction is the formation of gametes with half the genomic DNA content of a somatic cell. This reduction in genomic content is accomplished through meiosis that, in contrast to mitosis, comprises two subsequent chromosome segregation steps without an intervening $\mathrm{S}$ phase. In addition, meiosis generates new allele combinations through the compilation of new sets of homologous chromosomes and the reciprocal exchange of chromatid segments between homologues. Progression through meiosis relies on many of the same, or at least homologous, cell cycle regulators that act in mitosis, e.g., cyclin-dependent kinases and the anaphase-promoting complex/cyclosome. However, these mitotic control factors are often differentially regulated in meiosis. In addition, several meiosis-specific cell cycle genes have been identified. We here review the increasing knowledge on meiotic cell cycle control in plants. Interestingly, plants appear to have relaxed cell cycle checkpoints in meiosis in
\end{abstract}

Communicated by T. Dresselhaus.

A contribution to the Special Issue "HAPRECI-Plant Reproduction Research in Europe".

E. Wijnker · A. Schnittger $(\bowtie)$

Department of Molecular Mechanisms of Phenotypic Plasticity, Institut de Biologie Moléculaire des Plantes du Centre National de la Recherche Scientifique, Université de Strasbourg, 67084 Strasbourg, France

e-mail: arp.schnittger@ibmp-cnrs.unistra.fr

E. Wijnker · A. Schnittger

Trinationales Institut für Pflanzenforschung, Institut de Biologie Moléculaire des Plantes du Centre National de la Recherche Scientifique, Université de Strasbourg, 67084 Strasbourg, France comparison with animals and yeast and many cell cycle mutants are viable. This makes plants powerful models to study meiotic progression and allows unique modifications to their meiotic program to develop new plant-breeding strategies.

Keywords Arabidopsis - Meiosis · Cell cycle · Cyclin-dependent kinase $\cdot$ Cyclin $\cdot$ Recombination

\section{Breaking the rules of mitosis}

While the reasons why meiosis and sex have evolved are under debate (see review and hypothesis by Hoerandl and Hadacek in this issue of Plant Reproduction), it is widely accepted that meiosis was derived from mitosis (Wilkins and Holliday 2009; Cavalier-Smith 2010). Progression through mitosis, which typically generates two daughter cells that are genetically identical to the mother cell, is controlled by the activity of cyclin-dependent kinases (CDKs) (Morgan 1997) (Figs. 1, 2). Although the control machinery displays many species-specific variations and is subject to adaptation, the general principle of CDK-driven progression through mitosis appears to be conserved from humans to plants (Harashima et al. 2013).

In contrast to mitosis, meiosis does not generate genetic copies of the mother cell; instead, the nuclear DNA content is halved when two subsequent chromosome segregation events immediately follow one another without an intermittent $\mathrm{S}$ phase (Fig. 1). The first meiotic division is crucially different from a mitotic division since homologous chromosomes instead of sister chromatids segregate to opposite poles. Importantly, the first meiotic division generates new allele combinations. These result both from meiotic crossovers, i.e., the reciprocal exchange of DNA 


\section{Mitosis}
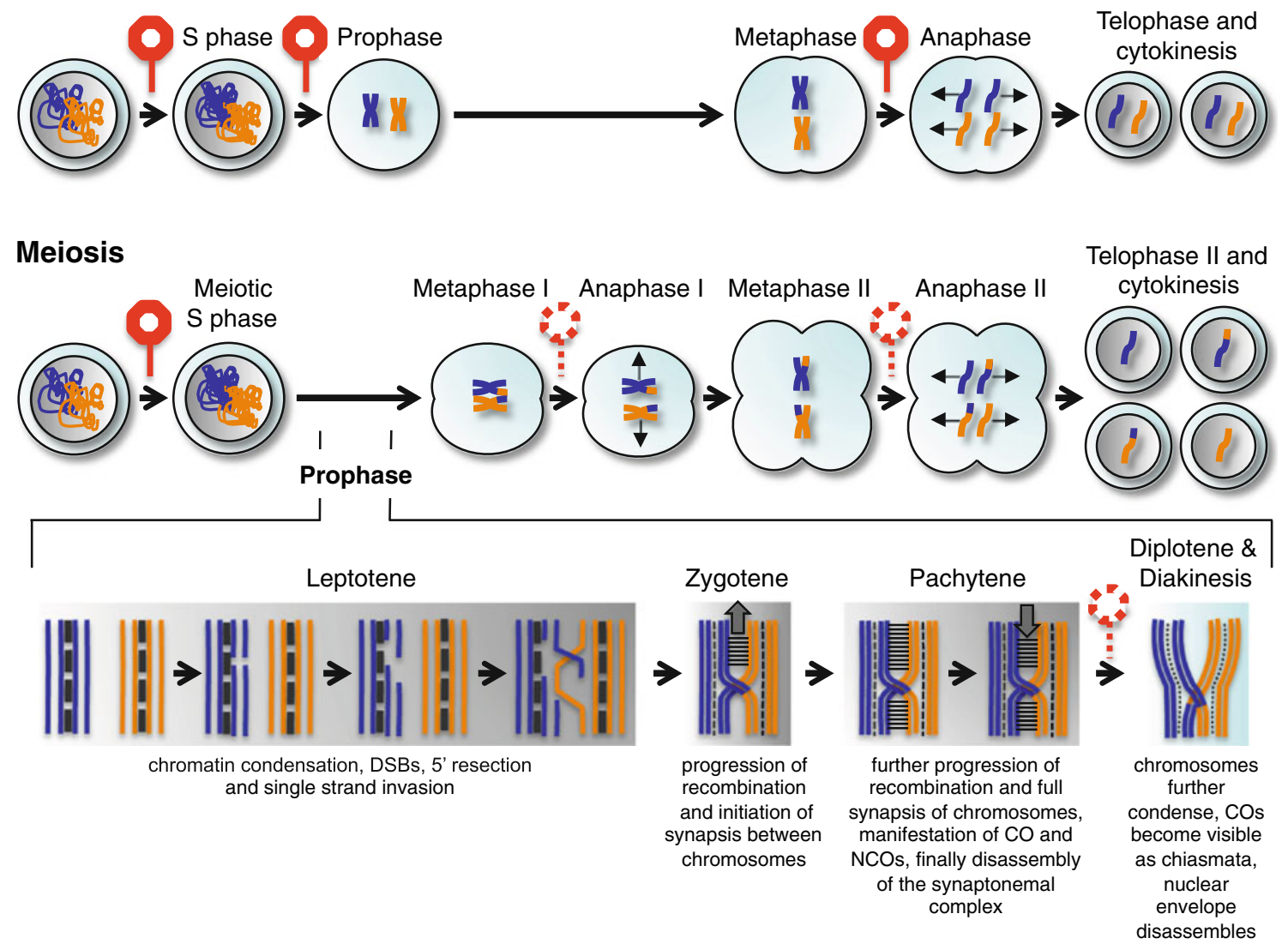

Fig. 1 Overview of a mitotic and meiotic division. Top panel major transitions in the mitotic cell cycle. Only one pair of homologous chromosomes is shown in orange and blue, with each line representing one chromatid. Chromatids duplicate during $\mathrm{S}$ phase, condense at prophase and segregate at anaphase followed by decondensation. Note the absence of the nuclear envelope during mitosis. The middle panel concurrent meiotic stages, with the first meiotic division added onto the mitotic program. Note that meiosis I is unique in segregating homologous chromosomes instead of chromatids. The segregation of sister chromatids at anaphase II resembles a mitotic division. The lower panel highlights different stages of the meiotic prophase; the events at the recombination sites are largely simplified, for a more detailed description see other reviews on this topic (Edlinger and

segments between homologues after repair of deliberately induced double-strand DNA breaks at prophase I, and from random homologue segregation at anaphase I (Fig. 1). During the second meiotic division, sister chromatids segregate, similar to a mitotic division (Fig. 1) (Brar and Amon 2008). To allow for the unique segregation of homologues during meiosis I, a special segregation machinery is present. This ensures that centromeric cohesion between the two sister chromatids of a chromosome is maintained during anaphase I and that their kinetochores are mono-oriented toward the same cell pole. Sister chromatid cohesion is then only completely lost in anaphase II when the kinetochores of both sister chromatids are attached to opposite spindles.
Schlogelhofer 2011; Osman et al. 2011). Please note that the leptotene stage shows the highest level of magnification, zygotene/pachytene is intermediate and diplotene/diakinesis shows the lowest magnification. Single blue and orange lines in this panel indicate single DNA strands, and two adjacent lines represent one chromatid. Doublestrand breaks (DSBs) in leptotene comprise the first steps of homologous recombination. Three mitotic checkpoints are highlighted with red signs. Meiosis in plants presumably shares one checkpoint at the beginning of meiotic $\mathrm{S}$ phase with the one found in animals and yeast (in red), whereas other meiotic checkpoints known from animals and yeast appear to be not present or function in a relaxed manner in plants (signs in red dashed lines)

In spite of these differences, entry and progression through meiosis are controlled by many of the same regulators as in mitosis, i.e., CDK-cyclin complexes and the anaphase-promoting complex/cyclosome (APC/C) (Pesin and Orr-Weaver 2008; Cooper and Strich 2011). Thus, a key question is how these complexes and activities are reprogrammed and adapted in meiosis to promote events that are strictly prohibited in a mitotic cycle and how advancement in meiosis is coordinated with recombination and chromosome distribution.

The focus of this review is on the cell cycle control aspect of meiosis in flowering plants. Excellent reviews on other aspects of plant meiosis, especially recombination, have been published elsewhere (Edlinger and Schlogelhofer 2011; Ma 


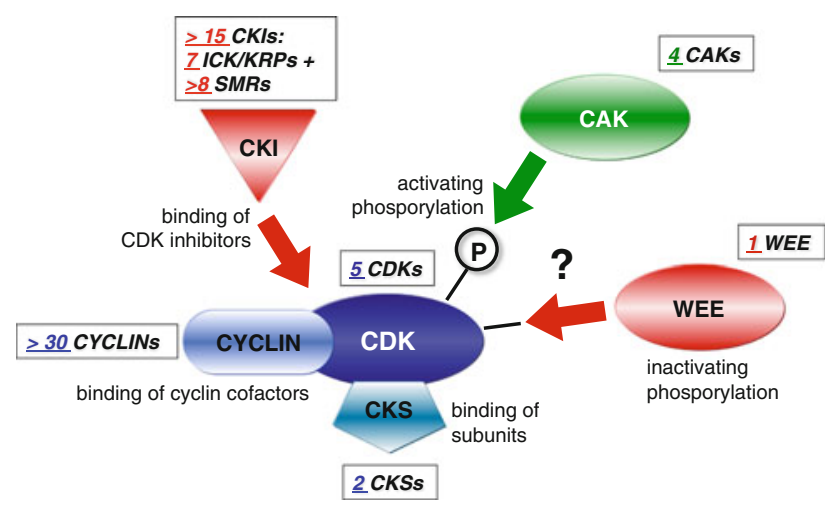

Fig. 2 Overview over the core cell cycle machinery in Arabidopsis. Progression through mitosis and meiosis is promoted by the activity of CDKs who require for full activity the binding of cyclin partners. These heterodimers can be regulated at multiple levels, e.g., binding of other subunits, CDK inhibitors and activating phosphorylation. The role of the inhibitory phosphorylation that is mediated by Wee1-type kinases in yeast and animals is not very well understood in plants and appears to be used in a different context than in other species. Analysis of cell cycle regulators is challenging in plants through the relatively high number of family members that often act at least partially redundantly. Here, the family sizes of the core cell cycle machinery components are given for Arabidopsis

2006; Osman et al. 2011; Mercier and Grelon 2008). After an introduction on the initiation and exit of the meiotic program, we summarize recent attempts to complete the parts list of meiotic cell cycle control machinery in plants. Focus will be on the function and regulation of CDK-cyclin complexes and the APC/C as major driving forces of meiosis. Finally, we summarize how the specialties of the plant meiotic program can be exploited in plant breeding.

\section{Starting the meiotic program}

Most plants, like the majority of all eukaryotes, reproduce sexually. During fertilization, the gametes from each parent fuse to give rise to a zygote from which the new organism develops. To prevent genome doubling in every new generation, the DNA content of the gametes has to be reduced through meiosis. Conversely, halving of chromosome number is strictly limited to occur only during gamete formation. Thus, special programs must exist to specify meiotic cells and to precisely control the entry as well as exit from the meiotic division program.

In animals, meiosis is executed by germ line cells that are separated from somatic cells during early embryogenesis (Wylie 1999). In flowering plants, however, meiotic cells, i.e., megaspore mother cells (by definition the female side) and microspore mother cells (male), are formed late during development, i.e., a subepidermal layer of archesporial cells differentiates into microspore mother cells in anther primordia, while megaspore mother cells differentiate from a single subepidermal cell in the tips of ovule primordia (Grossniklaus and Schneitz 1998; Goldberg et al. 1993). Substantial work over the last years has led to the identification of genetic pathways that are required for a meiotic cell fate. In case of the megaspore mother cell, this pathway includes the nuclear-localized protein SPOROCYTELESS/NOZZLE (SPL/NZZ) (Yang et al. 1999; Balasubramanian and Schneitz 2000) and the further downstream-acting homeobox transcription factor WUSCHEL (WUS) (Lieber et al. 2011; Groß-Hardt et al. 2002). WUS is required for the expression of two redundantly acting genes WINDHOSE 1 (WIHI) und WIH2 that encode novel peptides whose absence leads to the loss of a morphological distinguishable functional megaspore mother cell (Lieber et al. 2011). Possible receptors for the WIH peptides are the tetraspanin-type transmembrane protein TORNADO 2 (TRN2) and the leucine-rich repeat protein TRN1 (Lieber et al. 2011). However, WIH-TRN interactions still need to be confirmed, and it is also up to now not clear what the downstream targets of this putative signaling cascade are.

It has been found that in particular posttranscriptional regulation, i.e., at the RNA level, is important for germ cell specification. The identification of several mutants in the ARGONAUTE (AGO) family in Arabidopsis, maize and rice implicated small RNAs in regulating meiotic progression, the repression of germ cell fate in somatic tissues, or, as was shown in rice, by repressing a somatic fate in germ cells (Nonomura et al. 2007; Olmedo-Monfil et al. 2010; Singh et al. 2011). The importance of posttranscriptional regulation for megaspore mother cell fate specification has been further underlined by the identification of the SUPPRESSOR OF GENE SILENCING 3 (SGS3) and of RNA-DEPENDENT RNA POLYMERASE 6 (RDR6) (Olmedo-Monfil et al. 2010) whose mutations, like ago 9 in Arabidopsis, lead to multiple megaspore mother cells and function in the biogenesis of double-stranded RNA. Another possible link to posttranscriptional control of meiocyte fate comes from the analysis of MEIOSIS ARRESTED AT LEPTOTENE 2 (MEL2) in rice that encodes for protein with a RNA recognition motif. Loss of MEL2 function results in a failure of most meiocytes to enter meiotic $\mathrm{S}$ phase. The few cells that proceed to prophase arrest at early stages and show perturbed meiotic characteristics (Nonomura et al. 2011).

Other genes that affect meiocyte specification are not yet functionally understood but are possibly linked to transcriptional and/or posttranscriptional control. For instance, the mutation of two DNA methyltransferases in maize leads to unreduced gametes and multiple embryo sacs, exemplifying control at the chromatin level of both female and male meiosis (Garcia-Aguilar et al. 2010). AMEIOTIC 1 (AMI) encodes an unknown protein from 
maize, and most aml alleles lack all indications of meiotic prophase, suggesting a key role in establishing a meiotic program (Pawlowski et al. 2009). In one aml allele, however, prophase is apparently initiated but cells arrest in leptotene/zygotene stage (Pawlowski et al. 2009; Golubovskaya et al. 1993). The phenotype of mutants in a rice $A M 1$ homologue resembles the one seen in this later allele from maize, also resulting in meiotic arrest during early prophase (Che et al. 2011). In contrast to maize and rice, mutants in the closest homologue of $A M 1$ in Arabidopsisdesignated DYAD/SWITCH 1 (SWII) complete a meiotic program and give rise to viable gametes (Mercier et al. 2001; Agashe et al. 2002; Siddiqi et al. 2000; Motamayor et al. 2000). Nevertheless, dyad/swil show some similarities with aml since alleles were described in which female, but remarkably not male meiosis shows mitotic-like divisions resulting from a failure to undergo synapsis followed by an equational division in which sister chromatids segregate. Male meiosis is either unaffected, or shows the complete loss of sister chromatid cohesion during meiotic prophase (Motamayor et al. 2000; Agashe et al. 2002; Mercier et al. 2001). Thus, it is likely that AM1-type proteins have undergone species-specific diversification and/or are involved in many different processes including the entry into meiosis.

Currently, it is not clear how these developmental regulators of meiotic cell fate initiate the meiotic cell division program. Programming of meiosis already starts before or during the meiotic $\mathrm{S}$ phase. An indication for this is the observation that in most if not all organisms meiotic $\mathrm{S}$ phase is much longer than an $\mathrm{S}$ phase preceding mitosis (Bennett and Smith 1972; Holm 1977). Specialties of meiotic $\mathrm{S}$ phase include the loading of a meiosis-specific cohesion complex, including the RADIATION SENSITIVE 21 (RAD21)-family protein RECOMBINATION DEFICIENT 8 (REC8), onto chromatin that ensures sister chromatid cohesion throughout meiosis I.

Similar to the entry, also the exit from a meiotic program needs to be strictly controlled to maintain genome stability and gene dosage. This is especially important in plants since the spores generated after meiosis will undergo a few (in flowering plants) up to many mitotic divisions (in moss) during the gametophytic life phase. Remarkably, mutants for the Arabidopsis gene THREE DIVISION MUTANT 1 (TDM1)/MALE STERILE 5 (MS5)/POLLENLESS 3 that encodes a protein with a yet unknown function undergo a third meiotic division without intervening $\mathrm{S}$ phase, indicating a failure in shutting down the meiotic program (Ross et al. 1997; Sanders et al. 1999; Glover et al. 1998). Similar problems in meiotic exit were described for mutants in the cyclin-dependent kinase inhibitor Roughex in Drosophila (Gönczy et al. 1994; Foley and Sprenger 2001). The observation that a $t d m l$ phenotype can be phenocopied by expressing a non-degradable version of the meiotic A-type
Fig. 3 Hypothetical activity levels of CDK and APC/C complexes during mitosis and meiosis. a Progression through mitosis is thought to rely on increasing levels of CDK activity (black line). Medium levels of CDK activity are required for the induction of $\mathrm{S}$ phase, and high levels are necessary to promote $\mathrm{M}$ phase. Putative threshold levels for $\mathrm{S}$ phase are indicated by a horizontal green line, threshold concentrations for $\mathrm{M}$ phase by a red line. Please note that most likely CDK activity in plants is separated into $\mathrm{S}$ phase CDK-cyclin levels and $\mathrm{M}$ phase CDK-cyclin levels that are for simplicity reasons not separately shown here. In order to license the origins of replication for $\mathrm{S}$ phase, CDK activity as to be low. This is largely accomplished by the activity of the APC/C (indigo line) that mediates the degradation of cyclins at the end of mitosis and thus sets back CDK activity. APC/ $\mathrm{C}^{\mathrm{CDC} 20}$ requires phosphorylation by $\mathrm{CDK}$-cyclin complexes for activity but is kept largely inactive until anaphase. This inhibition will only be released if all chromosomes are attached to the mitotic spindle. The APC/C mediates then the degradation of securin which liberates separase that in turn cleaves the centromeric cohesions between sister chromatids (SC) to allow their subsequent segregation. After degradation of cyclins and drop of CDK activity, the APC/C is kept active by the Cdh1/Fzr/CCS52 adaptor protein. b During the meiotic $\mathrm{S}$ phase that typically takes much longer than a mitotic $\mathrm{S}$ phase, chromosomes are prepared for meiosis, for instance by the incorporation of the meiosis-specific cohesion REC8. Prophase I immediately starts after S phase (see also Fig. 1) that again typically takes much longer than the mitotic prophase. Dampening of APC/C activity and/or maintenance of CDK activity after anaphase I is crucial to prevent exit from meiosis and to establish interkinesis (the short phase between meiosis I and II) before meiosis II. To what level $\mathrm{CDK}$ and $\mathrm{APC} / \mathrm{C}$ activities are changed is purely speculative in the graph. $\mathbf{c}$ The second meiotic division is skipped in mutants like osd1/ gig and tam. Presumably, loss of TAM directly reduces CDK activity levels, while loss of OSD1 leads to full activation of the APC/C and hence a drop in CDK activity via degradation of meiotic cyclins. d Mutants in TDM and plants expressing a TAM mutant version in which the recognition sequence for the APC/C (destruction box) is mutated enter a third meiotic division in which then the sister chromatids are randomly distributed. It is plausible that such a third division, similar to the first and second division, is guided by raising and falling levels of CDK and APC/C activities. Mutants in TAM also slow down the progression of meiotic Prophase I, a feature that is not covered here

cyclin TARDY ASYNCHRONOUS MEIOSIS (TAM, see below) argues that TDM1 may also act in some way to restrict meiotic CDK activity (Cromer et al. 2012). However, while accumulating evidence also from plants indicates that meiotic exit is coupled to reduced CDK activity (see below), it is not clear yet how high CDK activity could possibly induce a third meiotic division.

\section{Progression through meiosis: the role of CDK-cyclin complexes}

Progression through the mitotic cell cycle has been found to rely on quantitative and qualitative aspects of CDKcyclin complexes (Fig. 3a). On the one hand, it has been found that oscillating levels of kinase activity drive the advancement in the cell cycle-a major regulator of this oscillation is the APC/C (see next chapter). For a cell to 

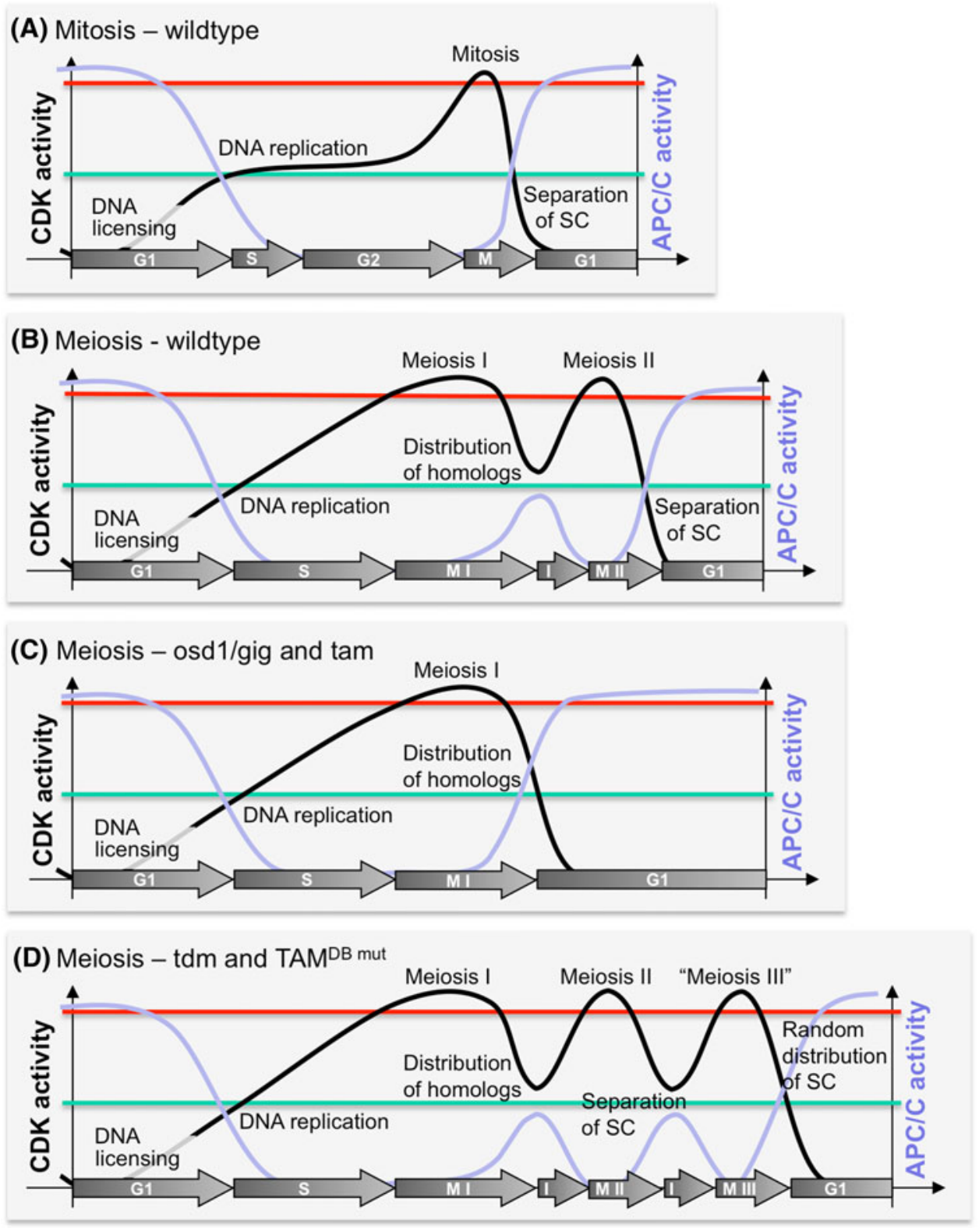

enter the DNA replication phase ( $\mathrm{S}$ phase) from a preceding gap phase $1(\mathrm{G} 1)$, the CDK-cyclin activity has to reach a certain threshold level. Then, a higher level of kinase activity is required for a cell to move from gap phase 2 (G2) that follows $S$ phase into mitosis (M phase). After mitosis, CDK activity drops which is required for new licensing of replication origins as a prerequisite for another S phase (Nasmyth 1996; Stern and Nurse 1996). These oscillations are thought to coordinate the different cell cycle events and promote a unidirectional progression in the cell cycle, e.g., by preventing untimely re-replication of the nuclear DNA before mitosis. Experimental evidence for this hypothesis has recently been provided by fission yeast cells that were engineered to have a chemically tunable CDK-cyclin complex (Coudreuse and Nurse 2010).

Cyclin-dependent kinases are regulated at multiple levels, and a key determinant of CDK activity is the amount and type of cyclin partners that are available (Pines 1995) (Fig. 2). There are typically S- and M-phase CDKs and cyclins. The general picture in animals is that D-type and E-type cyclins promote entry into $\mathrm{S}$ phase, while cyclin A controls $\mathrm{S}$ phase as well as early mitotic events, and B-type cyclins control mitosis (Pines 1995). Importantly, different CDK-cyclin complexes were found to have different, although sometimes partially overlapping, substrate specificities (Pagliuca et al. 2011). It is tempting to speculate 
that these specificities also contribute to the orchestration of the cell cycle.

In plants, clear homologues for A- and B-type cyclins have been found next to a cyclin class that has been named D-type cyclins but is equidistant to animal D- and E-type cyclins (Wang et al. 2004a). Similar to the situation in animals, different CDK-cyclin complexes appear to have distinct activity levels against different substrates (Harashima and Schnittger 2012; Nowack et al. 2012). Notably, many of the key components involved in recombination both in animals and plants harbor consensus CDK phosphorylation sites and/or cyclin-binding signatures, e.g., DISRUPTED MEIOTIC cDNA 1 (DMC1), REC8 and SPORULATION-DEFICIENT 11 (SPO11) (Esposito and Esposito 1969; Bishop et al. 1992; Ponticelli and Smith 1989), suggesting that not only the general progression through meiosis but also the meiosis-specific recombination events are orchestrated by CDK-cyclin complexes.

One complication to study cell cycle control in plants is the large number of some of the cell cycle regulators present in the genome. For instance, next to at least five central cell cycle CDKs (CDKA;1, CDKB 1;1, CDKB1;2, CDKB2;1 and CDKB2;2), there are more than 30 cyclins in Arabidopsis (Fig. 2) (Wang et al. 2004a; Vandepoele et al. 2002). Thus, an obvious first question is which cell cycle regulators are involved to drive plant meiosis.

Arabidopsis CDKA;1, which shows the highest level of similarity with Cdk1 and Cdk2 among the animal CDKs, appears to be predominantly involved in controlling $\mathrm{S}$ phase entry next to its role in mitosis (Nowack et al. 2012). Homozygous $c d k a ; 1$ mutants are viable but severely compromised, precluding clear developmental analyses (Nowack et al. 2012). Weak loss-of-function alleles of $C D K A ; 1$ were found to be completely sterile, and morphological analysis of male meiosis and gametogenesis indicated a central role in meiosis (Dissmeyer et al. 2007, 2009). A key role of CDKA;1 in meiosis is further supported by the immunolocalization of CDKA;1 during meiosis as well as the detection of functional CDKA;1YFP fusion proteins in meiocytes (Bulankova et al. 2010; Zhao et al. 2012).

Interestingly, an important chromosome pairing regulator of wheat, Pairing homeologous 1 (Phl), was proposed to be an epiallele of a wheat CDKA;1 homolog. The presence of $P h l$ prevents the recombination between the three homoeologous genomes (A, B and D) that are present in bred wheat and thus is a crucial determinant of wheat fertility (Riley and Chapman 1958). The Phl locus was mapped to a region of approximately $2 \mathrm{Mb}$ on chromosome 5B (Al-Kaff et al. 2008; Griffiths et al. 2006). In the center of this region lies a heterochromatic region, apparently translocated from chromosome 3A. Flanking this heterochromatic region resides a cluster of pseudo genes that show similarities to $C D K A ; 1$. It has been proposed that the heterochromatic region stimulates the production of small RNA specimens from the pseudo $C D K$ genes leading in turn to a down-regulation of the expression of endogenous CDKA-like genes (Griffiths et al. 2006). Further support for this hypothesis comes from the observation that removal of $P h l$ leads to a transcriptional up-regulation of CDKA-like genes on other chromosomes (Al-Kaff et al. 2008). CDK action is counter balanced by phosphatases (Fisher et al. 2012), and interestingly, treatment of wheat plants with okadaic acid, a phosphatase inhibitor, led to pairing of homeologous chromosomes resembling the loss of Phl (Knight et al. 2010; Greer et al. 2012). However, the mapping interval of $P h l$ is still large, and in the absence of direct functional evidence, it is currently not unambiguously clear whether $P h l$ encodes an epiallele of the wheat $C D K A$ kinase(s). Even if so, it is not at all understood how down-regulation of CDK activity could accomplish the complex phenotypes seen in $P h l$.

B1-type CDKs appear to function mostly in mitotic entry but have also some function in S phase (Nowack et al. 2012; Vanneste et al. 2011; Xie et al. 2010). The full fertility of the double mutant $c d k b 1 ; 1$ and $c d k b 1 ; 2$ indicates only a minor or redundant role of B1-type CDKs in meiosis. B2-type CDKs were found to accumulate specifically in M phase (Menges et al. 2005). Both, the downregulation by an RNAi approach as well as their overexpression resulted in severely compromised plants with malfunctioning shoot apical meristem precluding a judgment of a role in meiosis (Andersen et al. 2008). Given the similarities of the second meiotic division with mitosis (Fig. 1), it is at least tempting to speculate that CDKB2s have a role in meiosis II.

The first two cyclins in Arabidopsis that were shown to have a meiotic function are the A-type cyclin TAM, also called CYCA1;2, and SOLO DANCERS (SDS), an atypical cyclin that shows similarities with A- and B-type cyclins (Table 1). In weak tam mutants, progression through meiosis I and II is slowed down, hence the name. Null mutants in TAM exit the meiotic program after the first division and produce diploid gametes (Fig. 3c) (Magnard et al. 2001; Wang et al. 2004b; d'Erfurth et al. 2010; Bulankova et al. 2010). Although TAM is not only expressed in meiosis, its meiotic function appears to be specific among the A1-type cyclins since it was found to be the only A1-type cyclin expressed in meiosis (Bulankova et al. 2013). Consistently, mutants in the closely related CYCA1; 1 did not show any meiotic aberrations and even double mutants between cycal;1 and tam did not enhance the tam mutant phenotype (Cromer et al. 2012). TAM acts in a not yet fully understood genetic network with two other meiotic genes: SUPPRESSOR WITH MORPHOGENETIC EFFECTS ON GENITALIA 7 (SMG7) and TDMI 
Table 1 Synopsis of meiotic cell division regulators in Arabidopsis

\begin{tabular}{llll}
\hline Protein class & Name & Function & References \\
\hline CDK & CDKA;1 & $\begin{array}{l}\text { Homologue of yeast Cdc2/Cdc28 combining functional } \\
\text { elements of human Cdk1 and Cdk2, characterized by }\end{array}$ & $\begin{array}{c}\text { (Dissmeyer et al. 2007, 2009; Cromer } \\
\text { et al. 2012; Bulankova et al. 2010; }\end{array}$ \\
& $\begin{array}{l}\text { PSTAIRE signature in the cyclin- binding domain; present } \\
\text { throughout meiosis, localizes in particular to the organellar }\end{array}$ & $\begin{array}{l}\text { Harashima and Schnittger 2012; } \\
\text { Nowack et al. 2012; Zhao et al. 2012) }\end{array}$
\end{tabular}

CYCLIN

CYCA2;1

CYCA2;2

CYCA2;3

CYCA3;2

CYCA3;3

CYCA3;4

CYCB3;1

SDS

TAM Expressed in meiotic prophase from leptotene to pachytene,

(CYCA1;2) similar to $C Y C A 2 ; 1$, required for fast progression through

$\mathrm{APC} / \mathrm{C}$ inhibitor

OSD1 (GIG) expressed in somatic cells

Specifically expressed in meiosis and present throughout male meiosis I and II; mutant phenotype can be suppressed by mutations in SMG7 or TDM1; no meiotic function has been found for the closely related CYCA1;1, and double mutants between cycal;1 and tam do not show an enhanced tam mutant phenotype; also expressed in somatic cells

band that separates the two cell poles after meiosis I; essential for meiosis, in particular high kinase activity meiosis I; builds active complex with SDS and TAM; also expressed in somatic cells

Like TAM expressed from leptotene to pachytene; also

Present in leptotene, localized to nuclei; also expressed in somatic cells; mutants do not show meiotic defects; however, the triple mutant with cyca2;3 and cyca2;4 has defects in chromosome condensation and segregation

romoter reporter lines suggest no expression during meiosis; however, the triple mutant with $c y c a 2 ; 2$ and $c y c a 2 ; 4$
defects in chromosome condensation and segregation

Promoter reporter lines suggest no expression during meiosis; however, the triple mutant with cyca2;2 and cyca2;3 has defects in chromosome condensation and segregation

Present in leptotene, localized in nuclei, also expressed in somatic cells; mutants do not show meiotic defects meiosis I and II; no obvious destruction box; mutants do not show meiotic defects

Present in leptotene, localized in nuclei, also expressed in somatic cells; mutants do not show meiotic defects reporter lines, present from zygotene to metaphase I, where it localizes to the spindle, reappears in metaphase II where it again localizes to the spindle; also expressed in somatic cells, CYCB3;1 inhibits precocious cell wall formation in meiosis redundantly with SDS

Atypical meiosis-specific cyclin that displays similarities with A- and B-type cyclin; expressed throughout meiosis and no obvious destruction box found; $s d s$ mutants display defects in homologue pairing and crossover formation during prophase I, leading to greatly reduced levels of meiotic recombination; SDS protein interacts with both CDKA; 1 and CDKB $1 ; 1$ in yeast two-hybrid interaction assays but has only high kinase activity with CDKA;1 in vitro; ectopically positioned cell walls in low percentage of $s d s$ mutants that are strongly enhanced in double mutants with $c y c b 3 ; 1$

Expression not determined; mutants exit the meiotic program after meiosis I; mutants develop cells with increased DNA content through endomitosis in vegetative tissues; interacts with the APC/C coactivators CDC20 and CCS52A1; genetic evidence from vegetative cells indicates an inhibitory function in particular for CDC20; can be phosphorylated by CDKA;1-TAM complexes in vitro
(Bulankova et al. 2013)

(Bulankova et al. 2013; Vanneste et al. 2011)

(Bulankova et al. 2013; Vanneste et al. 2011)

(Bulankova et al. 2013; Vanneste et al. 2011)

(Bulankova et al. 2013)

(Bulankova et al. 2013)

(Bulankova et al. 2013)

(Bulankova et al. 2013)

(Azumi et al. 2002; Chang et al. 2009; De Muyt et al. 2009; Bulankova et al. 2013; Harashima and Schnittger 2012)

(Magnard et al. 2001; Wang et al. 2004b; d'Erfurth et al. 2010; Bulankova et al. 2010; Bulankova et al. 2013)

(d'Erfurth et al. 2009; Cromer et al. 2012; Iwata et al. 2011) 
Table 1 continued

\begin{tabular}{|c|c|c|c|}
\hline Protein class & Name & Function & References \\
\hline $\begin{array}{l}\text { TPR-repeat } \\
\text { domain protein } \\
\text { with a } 14-3-3 \\
\text { domain }\end{array}$ & SMG7 & $\begin{array}{l}\text { Expression in meiosis not clear; SMG7 is involved in } \\
\text { Nonsense-Mediated RNA decay (NMD); mutants have } \\
\text { pleiotropic phenotypes caused by an autoimmune-like } \\
\text { response; in meiosis, loss of SMG7 results in an arrest after } \\
\text { anaphase II; appears to act in the same genetic pathway as } \\
\text { TDM1 }\end{array}$ & $\begin{array}{l}\text { (Bulankova et al. 2010; Riehs-Kearnan } \\
\text { et al. 2012; Riehs et al. 2008) }\end{array}$ \\
\hline $\begin{array}{l}\text { Plant-specific } \\
\text { protein with } \\
\text { unknown } \\
\text { function }\end{array}$ & $\begin{array}{l}\text { TDM } 1 \\
\text { (MS5, } \\
\text { POLLEN- } \\
\text { LESS3) }\end{array}$ & $\begin{array}{l}\text { Expression in meiosis not clear; represses a third meiotic } \\
\text { division through an unknown mechanism; is epistatic to } \\
\text { mutants in TAM and SMG7 }\end{array}$ & $\begin{array}{l}\text { (Sanders et al. 1999; Bulankova et al. } \\
\text { 2010; Ross et al. 1997; Glover et al. } \\
\text { 1998) }\end{array}$ \\
\hline
\end{tabular}

(see sections on meiotic entry and meiotic checkpoints). While loss of SMG7 results in arrest at anaphase II, the double mutant tam smg7 also progresses till this arrest point, i.e., the effect of tam can be suppressed by mutations in SMG7 (Bulankova et al. 2010). Similarly, unexpected was the finding that the $t d m 1$ mutant phenotype, resulting in a third meiotic division, is epistatic to the arrest after the first meiotic division seen in tam (Bulankova et al. 2010). Finally, meiosis in a smg $7 \mathrm{tdml}$ double mutant was found to overcome the smg 7 arrest point and normally progress to telophase II where after it even entered a third meiotic division as seen in $t d m 1$ mutants. These genetic analyses link TDM1 and SMG7 to the regulation of CDK activity.

The atypical cyclin SDS is specifically expressed in meiosis, and $s d s$ mutants display defects in homologue pairing and formation of crossovers during prophase I, leading to greatly reduced levels of meiotic recombination (Azumi et al. 2002; Chang et al. 2009; De Muyt et al. 2009; Bulankova et al. 2013). SDS activity is required for the recruitment of the recombinase DMC1 to chromosomes (De Muyt et al. 2009). SDS has been found to interact with both CDKA;1 and CDKB1;1 in yeast two-hybrid interaction assays (Azumi et al. 2002), but in in vitro kinase assays, SDS showed high activity only in conjunction with CDKA;1 (Harashima and Schnittger 2012).

Recently, all A- and B-type cyclins of Arabidopsis were assessed for expression during meiosis, and distinct meiotic accumulation patterns were found for eight of them providing a framework for further studies (Table 1) (Bulankova et al. 2013). CYCA2;2, CYCA3;2; CYCA3;3, CYC3;4 and SDS were detected already early in Prophase. In mid Prophase, besides TAM also CYCA2;1 appeared while CYCA2;2, CYCA3;2 and CYCA3;4 disappeared. CYCB3;1 specifically accumulated in Metaphase I and Metaphase II and localized to the spindle. Next to SDS, only CYCA3;3 was found to be present throughout meiosis. However, no mutant phenotype was found in cyca3;3 mutants and similarly no perturbation of the meiotic program was found in cyca3;2 or cyca3;4 mutants. However, a redundant function of the three meiotically expressed A3- type cyclins cannot be ruled out at the moment (Bulankova et al. 2013).

Unexpectedly, given its localization to the spindle in late meiosis I and II, mutants in $C Y C B 3 ; 1$, the only B-type cyclin that was found to be expressed in meiosis, showed the formation of cell wall-like structures from prophase I through entire meiosis (Bulankova et al. 2013). A closer examination revealed that ectopically positioned cell walls are also formed in low percentage of $s d s$ mutants and indeed, introgression of $s d s$ into the $c y c b 3 ; 1$ mutant background strongly enhanced this phenotype. Thus, SDS and CDKB3;1 appear to have multiple and likely not connected roles during meiosis; first in orchestrating recombination (SDS) and presumably spindle formation (CDKB3;1) and second in contributing to general kinase levels preventing the formation of premature cytokinesis.

The question as to which cyclins are involved in meiosis is likely more complex than suggested by the above-mentioned expression patterns. For instance, both $C Y C A 2 ; 3$ and CYCA2;4 were not found to be present in meiosis, and mutants in $C Y C A 2 ; 1$ and $C Y C A 2 ; 2$ were fully fertile. However, the triple mutant cyca2;2 cyca2;3 cyca2;4 shows defects in chromosome condensation and segregation, arguing either for low expression/masked detection of CYCA2;3 and/or CYCA2;4 or for a complex compensatory interaction in which normally not expressed A2-type cyclins become up-regulated in a single-mutant background (Bulankova et al. 2013). Nonetheless, the very defined expression and localization patterns of the different cyclins argues that, instead of one single central regulator, many distinct CDK-cyclin dimers with partially overlapping functions drive progression through plant meiosis.

\section{Progression through meiosis: APC/C control}

The APC/C, whose activity is coupled to CDK action, is one of the most important regulators of the mitotic cell cycle. It is a large 1.5 MDa multi-subunit E3 ubiquitin ligase that marks target proteins for degradation by the 
proteasome. The two major functions of the APC/C are the mediation of the turnover of cyclins and securin, an inhibitor of separase that cleaves the centromeric cohesion of sister chromatids and by that promotes the progression of Anaphase. These functions appear to be conserved in all eukaryotes although the APC/C might have been additionally recruited for developmental roles in a speciesspecific manner (Marrocco et al. 2010; Peters 2006; Heyman and De Veylder 2012).

In a simplified view, high CDK levels promote APC/C activity by phosphorylating several components, among them CDC20, a WD40 repeat-containing coactivator, that is important for the recognition of substrates such as B-type cyclins (Pesin and Orr-Weaver 2008). Through the action of the spindle checkpoint (see also next section), the APC/ $\mathrm{C}$ largely remains inactive until all sister chromatids are attached to the mitotic spindle and under tension indicating an equal alignment of the chromosomes in the metaphase plate and allowing subsequently their equal distribution (Jia et al. 2013; Lara-Gonzalez et al. 2012). The activated APC/C eliminates kinase activity through degradation of cyclins (Fig. 3). This, in turn, also shuts down APC/C ${ }^{\mathrm{CDC} 20}$ activity itself. However, there is a related coactivator protein for the APC/C, Cdh1/Fzr, known as CELL CYCLE SWITCH PROTEIN 52 (CCS52) in plants (Cebolla et al. 1999), that functions at low CDK levels and maintains APC/C activity during the exit from mitosis and in G1 (Fig. 3) (Peters 2006).

In animals and yeast, the $\mathrm{APC} / \mathrm{C}$ was found to be required for both meiosis I and meiosis II (Cooper and Strich 2011). For the progression from metaphase I to anaphase I, the APC/C needs to degrade the separase inhibitor securin, like it does in mitosis. Separase then cleaves the meiotic cohesin REC8 along the chromosome arms, allowing the resolution of chiasmata between homologous chromosomes and their segregation to opposite poles. However, REC8, protected by Shugoshin (Kitajima et al. 2004), is not destroyed in the centromeric regions because of which the two sister chromatids of each homologous chromosome remain connected. Through different mechanisms, the kinetochores of both sister chromatids are oriented in the same direction or reduced to only one functional kinetochore. The centromeric REC8 is finally cleaved in meiosis II, allowing the separation of sister chromatids, resembling the situation in mitosis (Brar and Amon 2008).

As outlined above, the activation of the APC/C in mitosis results in a drop of $\mathrm{CDK}$ activity and initiates a mitotic exit program. Studies in animals and yeast have shown that CDK activity is kept high after meiosis I by dampening APC/C-mediated proteolysis and by increased synthesis of meiotic cyclins (Hochegger et al. 2001; Izawa et al. 2005; Borgne et al. 2002; Gross et al. 2000). The requirement for high $\mathrm{CDK}$ activity to prevent cytokinesis after Arabidopsis meiosis I is highlighted by the phenotypes of tam null mutants that terminate meiosis after the first division and hypomorphic $c d k a ; 1$ mutants that also appeared to make a cell wall after only one division (Dissmeyer et al. 2007; Bulankova et al. 2010; d'Erfurth et al. 2010). Consistently, active CDKA;1 complexes were detected at the organellar bands that separate the two cell poles after meiosis I where they may prevent cytokinesis (Bulankova et al. 2010).

Furthermore, there is evidence that the maintenance of elevated $\mathrm{CDK}$ activity after meiosis I is linked to the regulation of APC/C in Arabidopsis similar to the situation in animals; since, mutants in an APC/C inhibitor protein called OMISSION OF SECOND DIVISION 1 (OSD1)/ GIGAS CELL (GIG) exit meiosis after the first division (Cromer et al. 2012; d'Erfurth et al. 2009). Studies of vegetative cells revealed that OSD1/GIG represses the action of CDC20 (Iwata et al. 2011). The analysis of CDC20 function is complicated by the presence of five presumably redundantly acting CDC20 genes in Arabidopsis. The simultaneous silencing of CDC20.1 and CDC20.2 via RNAi resulted in plants that produced very little pollen (Kevei et al. 2011). However, a detailed description of the function of CDC20 in the meiotic program is still pending.

Putative substrates of a meiotic APC/C ${ }^{\mathrm{CDC} 20}$ complex are TAM, the other being above-mentioned A-type cyclins as well as CYCB3;1. The two cyclins that are present throughout meiosis, CYCA3;3 and SDS, (Bulankova et al. 2013), lack or only have a degenerated destruction box, which serves as a recognition sequence for CDC20 (Glotzer et al. 1991). Interestingly, adding a destruction box prevents accumulation of SDS beyond pachytene similar to CYCA2;2, CYCA3;2 and CYCA3;4, which suggests that the $\mathrm{APC} / \mathrm{C}$ becomes already active in mid prophase. In animals, cyclin $\mathrm{A}$ is also degraded before cyclin $\mathrm{B}$ in a yet not fully understood mechanism (Ramachandran et al. 2007; Fung et al. 2005). How a sequential turn-over of Aand B-type cyclins in plant meiosis is accomplished needs to be determined, but defined degradation steps could possibly contribute to the orchestration of the many different events necessary in meiosis.

\section{Meiotic checkpoints}

Progression through the mitotic cycle is controlled at several transition points, also called checkpoints (Fig. 1). A first prominent checkpoint guards the entry into $\mathrm{S}$ phase (G1-S transition point) and requires that the activity of S-phase-specific CDK-cyclin complexes exceed a threshold level. A second checkpoint controls the entry into 
mitosis (G2-M transition point) and depends on M-phasespecific CDK-cyclin activity. Finally, a spindle checkpoint controls the activity of the APC/C and guards the metaphase-anaphase transition by assuring that all chromosomes are aligned on the equatorial plate and are attached to the mitotic spindle. In yeast and animals, several meiotic checkpoints have been identified that roughly correspond to these mitotic checkpoints. In contrast, meiotic checkpoints appear to be very differently setup in plants.

In yeast, the first meiotic checkpoint is the entry control into meiotic S phase (Fig. 1), for which the metabolic state of a cell appears to be of key importance as starvation induces meiosis (Egel 1971). While reports on meiotic arrests in plants are mounting, these seem of a different nature and not necessarily represent a checkpoint (see previous section on meiotic entry). In any case, entry into a meiotic program in plants does not appear to involve nutrient availability.

In animals and yeast, a meiosis-specific checkpoint, designated meiotic recombination checkpoint, is present at the end of pachytene stage permitting entry into diplotene stage only if the recombination process has been successfully completed (Roeder and Bailis 2000). By keeping the homologous chromosomes connected, properly processed crossovers are thought to allow the meiotic spindle to build up tension and this serves as a sign that the chromosomes can then be equally distributed to opposite poles of the cell (see also section on the APC/C) (Cooper and Strich 2011). The absence of this tension, as is presumably the case in mutants impaired in meiotic recombination such as mutants in the recombinase Dmc1 and homologous RecA family genes, triggers this pachytene checkpoint resulting in arrest of the meiotic program until spindle tension is established (Rockmill et al. 1995; Ghabrial and Schüpbach 1999; Takanami et al. 1998; Gartner et al. 2000; Odorisio et al. 1998). In mammals, a prolonged meiotic arrest can even lead to programmed cell death (Pittman et al. 1998; Yoshida et al. 1998). Without such a checkpoint, any absence of crossovers or failures in attaching the meiotic spindle to kinetochores would bear the risk of chromosome missegregation and subsequent aneuploidy resulting in severe developmental anomalies. Strikingly, a pachytene checkpoint appears to be not present or at least only in a much relaxed form in Arabidopsis since for example mutants in DMC1 can complete meiosis (Couteau et al. 1999; De Muyt et al. 2009).

The pachytene checkpoint has been found to rely on many of the components of the mitotic DNA damage checkpoint (Wohlbold and Fisher 2009), and meiotic arrest is alleviated if mitotic DNA damage checkpoint components are inactivated (Lydall et al. 1996). In particular, the pachytene checkpoint has been found to depend on Wee1type kinases, which catalyze phosphorylation of highly conserved Thr and/or Tyr residues in the P-loop of Cdk1type kinases and by that block their activity (Berry and Gould 1996; Leu and Roeder 1999) (Fig. 2). Consistently, mutations in Cdc28, a Cdk1 homologue and the major CDK in budding yeast, cause arrest in pachytene (Shuster and Byers 1989). However, even in mutants that fail repairing meiotic DSBs in plants and hence suffer from massive chromosome fragmentation, the developmental program leading to the formation of gametes is typically completed. These mutants include completion of meiotic recombination 1/sporulation in the absence of spo eleven 2 (coml/sae2), meiotic recombination 11 (mrel1), rad50, and rad51 (Uanschou et al. 2007; Gallego et al. 2001; Doutriaux et al. 1998; Li et al. 2004; Hartung and Puchta 1999; Bundock and Hooykaas 2002; Puizina et al. 2004).

The relaxed nature of the pachytene checkpoint in plants could at least be partially due to different mechanisms of how plants arrest the cell cycle after DNA damage. Although WEE1 homologues exist in plants and have for instance been isolated from maize, tomato, and Arabidopsis (Sun et al. 1999; Sorrell et al. 2002; Gonzalez et al. 2004), WEE1 function appears to have undergone functional diversification since at least in Arabidopsis, weel mutants neither have mitotic problems nor are impaired to arrest the cell cycle after DNA double-strand breaks (De Schutter et al. 2007; Cools et al. 2011). Also, dephosphomutants in CDKA; 1 that cannot be phosphorylated by WEE1 are viable and not hypersensitive to DNA-damaging drugs (Dissmeyer et al. 2009, 2010). Consistently, recent observations suggested that instead of controlling cell cycle progression via CDKA;1, Arabidopsis WEE1 prevents premature cell differentiation after DNA damage in S phase in a yet unknown mechanism (Cools et al. 2011).

The last two major checkpoints in meiosis are the transition points from metaphase I to anaphase I and from metaphase II to anaphase II. In yeast and animals, these checkpoints resemble the mitotic spindle checkpoint that detects unattached chromosomes in order to prevent aneuploidy. However, at least the metaphase I to anaphase I checkpoint also does not appear to be very potent in plants since many mutants, i.e., in the above-mentioned SPO11 or DMCl genes required for the induction, respectively processing of meiotic double-strand breaks, do not arrest anaphase I, but progress through meiosis and often lead to aneuploidy (Couteau et al. 1999; Hartung et al. 2007).

The less stringent meiotic checkpoints also appear to be relevant during wild-type plant development reflected by the relatively high number of spontaneous diploid pollen produced (De Storme and Geelen 2013; Brownfield and Kohler 2011). This has also evolutionary consequences as the formation of unreduced gametes is a major driving force in polyploidization and subsequently in speciation 
(Comai 2005; Kohler et al. 2010; Otto 2007). It is an interesting hypothesis that the occurrence of relaxed checkpoints is not only a byproduct of some not yet understood molecular mechanisms but may happen in a deliberate and controlled manner contributing to evolutionary plasticity of plants.

Remarkably, the metaphase I to anaphase I checkpoint appears to be differentially active in mammals since males but not, or least not very efficiently, females arrest meiosis after chromosomal misalignments, leading to chromosome aberrations such as trisomy 21 in humans (LeMaire-Adkins et al. 1997; Woods et al. 1999). There is also a not very well understood time component involved since the occurrence of chromosome aberrations increases with age of the females.

While proof for the existence of the meiotic checkpoints is missing in plants, we also still know only little about the kinetics of meiosis in the above-described mutants and there may be substantial delays in cell cycle progression that would implicate some checkpoint mechanisms in place. Furthermore, there may exist different control points not known in yeast or animals. For example, mutation of aml and mel2 that disrupt a cells' commitment to meiosis can cause early meiotic arrest in plants and lead the authors to suggest the presence of a meiotic leptotene/zygotene checkpoint (Che et al. 2011; Pawlowski et al. 2009) (see section above). Its nature might fundamentally differ from the DNA-damage-induced pachytene checkpoint as it is likely a consequence of pre-meiotic events (Nonomura et al. 2011). DUET/MALE MEIOCYTE DEATH1 (MMD1), a PHD finger protein, causes male meiocytes to arrest and undergo apoptosis at the end of meiotic prophase diakinesis/metaphase I (Reddy et al. 2003; Yang et al. 2003). It shows homology to MALE STERILITY1 (MS1), a transcriptional regulator of male gametogenesis the mutation of which causes arrest of microspore development (Ito et al. 2007; Wilson et al. 2001). Mutants of BLAP75 and Topoisomerase $3 \alpha$ (TOP $3 \alpha$ ) that act together in the dissolution of homologous recombination intermediates cause arrest after chromosomes fragment at anaphase/telophase I (Chelysheva et al. 2008; Hartung et al. 2008). Fragmentation per se does not induce meiotic arrest, since rad51 mutants, which also show fragmentation at meiosis I, progress through meiosis and can even rescue the TOP $3 \alpha$ telophase I arrest. Lastly, mutants in the presumptive-phosphoserine-binding protein SMG7 become arrested at the anaphase II to telophase II transition and are characterized by a failure to decondense chromosomes and reorganize the meiosis II spindle (Riehs et al. 2008). However, which of these various arrest points are genuine checkpoints or rather reflect the lack of an essential component necessary for the next step in the meiotic program needs to be determined in future.
Exploiting the special features of the meiotic program in plants

The absence/low stringency of meiotic cell cycle checkpoints in plants offers an unprecedented possibility in breeding. Two novel breeding methods were recently shown to be feasible in plants (Arabidopsis) that make use of specific meiotic mutant situations to engineer new inheritance patterns. Notably, these mutant situations (a triple mutant of spol1, rec8 and $o s d 1$ or the RNAi-induced knock down of DMCl) would all have caused checkpointinduced meiotic arrest in mouse (Romanienko and Camerini-Otero 2000; Bannister et al. 2004; Yoshida et al. 1998).

Marimuthu et al. (2011) described the construction of a spol1 rec8 osd11 triple mutant in Arabidopsis in the F1 of a cross between two natural accessions (i.e., a plant homozygous for the mutations, but heterozygous for all other alleles present between the two accessions). In this triple mutant, no recombination occurs, sister chromatids segregate at meiosis I and the second meiotic division is omitted. Consequently, these plants execute a mitosis-like meiotic cell division that produces viable diploid spores with a genotype identical to the parent. Since in Arabidopsis, haploid or diploid gametes can directly be grown into seeds and subsequently into plants (Ravi and Chan 2010; Marimuthu et al. 2011), it was possible to grow offspring from this F1, which were identical to the mother plant, thereby effectively cloning the F1 through seeds (Marimuthu et al. 2011) (Fig. 4). Since contemporary breeding relies heavily on heterozygous varieties that are

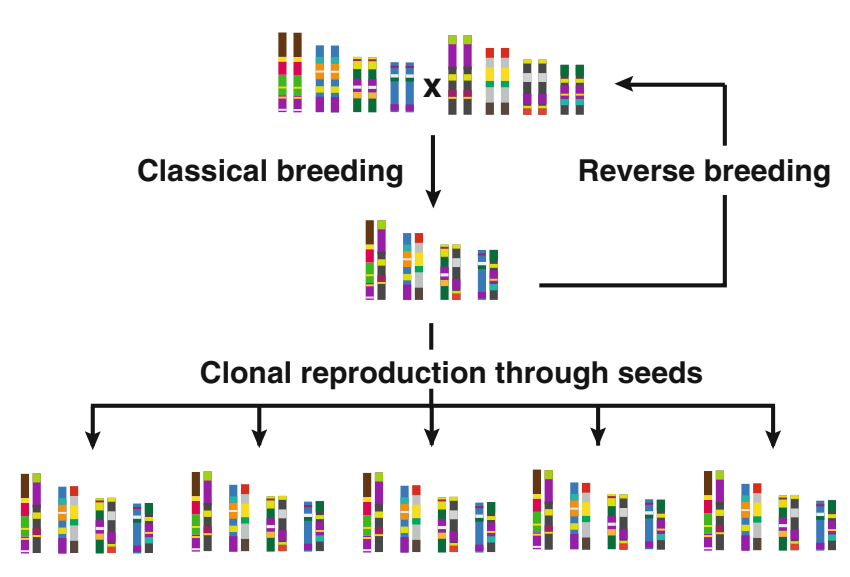

Fig. 4 Relaxed meiotic checkpoints allow the development of new breeding approaches. Classical breeding refers to the classical method of constructing a hybrid by crossing two homozygous lines. Reverse breeding allows homozygous breeding lines to be constructed directly from a heterozygous parent essentially reversing classical breeding. Clonal reproduction through seeds allows the propagation of hybrids without homozygous intermediates. Please note that the given breeding schemes are simplified representations of these techniques. For further information please see Marimuthu et al. (2011), Wijnker et al. (2012) and Dirks et al. (2009) 
preferred because of their higher yield (Chen 2010), this modulation of meiosis may show a way how to propagate heterozygote crops as clonal lines rather than creating them anew each year by crossing homozygous parental lines.

A second proposed breeding method, reverse breeding, aimed at developing a technique to dramatically reduce the complexity of meiotic recombination, in which not alleles, but only non-recombinant parental chromosomes segregate (Wijnker et al. 2012). The authors showed the possibility to "deconstruct" a heterozygous genome into homozygous breeding lines carrying exactly half of the parental chromosomes. So when a potentially interesting, high producing heterozygous plant is encountered in an outcrossing population, it could be directly converted into homozygous (new parental) breeding lines (Fig. 4). In this case, a dominant RNAi-mediated knock down of the essential meiotic recombinase DMC1 abolished crossover formation in a heterozygous F1 and as a consequence resulted in missegregation of chromosomes leading to semi-sterility because of aneuploid gametes. However, the non-arrested progression of the meiotic program nevertheless ensures that cells in which-by chance-balanced chromosome segregation takes place, still produce viable gametes. These gametes containing non-recombinant chromosomes can be grown into haploid offspring, as mentioned above, and can subsequently be converted into homozygous diploid plants (so called doubled haploids). From among these doubled haploids, parental lines can be selected to reproduce the initially isolated hybrid. Reverse breeding is a potential versatile breeding tool that, apart from generating breeding lines for heterozygotes, could be used to produce chromosome substitution lines (Dirks et al. 2009).

\section{Conclusions}

A detailed understanding of meiotic progression in plants is not only important for basic insights into one of the largest classes of living organisms and crucial components in most ecosystems on earth but also for emerging questions in speciation and genomic dynamics for which plants provide powerful model systems. The viability of many plant cell cycle and meiotic mutants furthermore allows the analysis of double mutants and the untangling of epistatic interactions, as was nicely illustrated through the experiments on the interactions between $\operatorname{smg} 7$, tam and $t d m$. The list of meiotic cell cycle regulators in plants is rapidly growing with major accomplishments just over the last few years. A main challenge in the future will be to untangle the specific from the redundant functions of the different CDK-cyclin complexes apparently at work in meiosis. Of key importance is the identification of the targets of these complexes and how their differential phospho-status will then promote the coordinated progression of the complex meiotic events. An immediate application of a deeper understanding of plant meiosis is the development of new plant-breeding strategies that may allow the propagation of hybrids and show the possibility to reconstruct complex allelic combinations. Thus, further insights into the regulation of the meiotic division program hold the promise for yet new possibilities in breeding to meet the challenges of our agriculture in the twenty-first century.

Acknowledgments We are grateful to Maren Heese for critical reading and helpful comments on the manuscript. This work was supported by a COST action of the European Union (HAPRECI), an European Union Interreg IV project, an European Research Council Starting Independent Researcher Grant and a Grant from the Agence Nationale de la Recherche to A.S.

Open Access This article is distributed under the terms of the Creative Commons Attribution License which permits any use, distribution, and reproduction in any medium, provided the original author(s) and the source are credited.

\section{References}

Agashe B, Prasad CK, Siddiqi I (2002) Identification and analysis of DYAD: a gene required for meiotic chromosome organisation and female meiotic progression in Arabidopsis. Development 129:3935-3943

Al-Kaff N, Knight E, Bertin I, Foote T, Hart N, Griffiths S, Moore G (2008) Detailed dissection of the chromosomal region containing the $\mathrm{Ph} 1$ locus in wheat Triticum aestivum: with deletion mutants and expression profiling. Ann Bot 101:863-872

Andersen SU, Buechel S, Zhao Z, Ljung K, Novak O, Busch W, Schuster C, Lohmann JU (2008) Requirement of B2-type cyclindependent kinases for meristem integrity in Arabidopsis thaliana. Plant Cell 20:88-100

Azumi Y, Liu D, Zhao D, Li W, Wang G, Hu Y, Ma H (2002) Homolog interaction during meiotic prophase $\mathrm{I}$ in Arabidopsis requires the SOLO DANCERS gene encoding a novel cyclinlike protein. EMBO J 21:3081-3095

Balasubramanian S, Schneitz K (2000) NOZZLE regulates proximaldistal pattern formation, cell proliferation and early sporogenesis during ovule development in Arabidopsis thaliana. Development 127:4227-4238

Bannister LA, Reinholdt LG, Munroe RJ, Schimenti JC (2004) Positional cloning and characterization of mouse mei8, a disrupted allele of the meiotic cohesin Rec8. Genesis 40:184194

Bennett MD, Smith JB (1972) The effects of polyploidy on meiotic duration and pollen development in cereal anthers. Proc R Soc Lond B Biol Sci 181:81-107

Berry LD, Gould KL (1996) Regulation of Cdc2 activity by phosphorylation at T14/Y15. In: Meijer L et al (eds) Progress in cell cycle research. Plenum Press, NewYork

Bishop DK, Park D, Xu L, Kleckner N (1992) DMC1: a meiosisspecific yeast homolog of $E$. coli recA required for recombination, synaptonemal complex formation, and cell cycle progression. Cell 69:439-456

Borgne A, Murakami H, Ayte J, Nurse P (2002) The G1/S cyclin Cig2p during meiosis in fission yeast. Mol Biol Cell 13:2080-2090 
Brar GA, Amon A (2008) Emerging roles for centromeres in meiosis I chromosome segregation. Nat Rev Genet 9:899-910

Brownfield L, Kohler C (2011) Unreduced gamete formation in plants: mechanisms and prospects. J Exp Bot 62:1659-1668

Bulankova P, Riehs-Kearnan N, Nowack MK, Schnittger A, Riha K (2010) Meiotic progression in Arabidopsis is governed by complex regulatory interactions between SMG7, TDM1, and the meiosis I-specific cyclin TAM. Plant Cell 22:3791-3803

Bulankova P, Akimcheva S, Fellner N, Riha K (2013) Identification of Arabidopsis meiotic cyclins reveals functional diversification among plant cyclin genes. PLoS Genet 9:e1003508

Bundock P, Hooykaas P (2002) Severe developmental defects, hypersensitivity to DNA-damaging agents, and lengthened telomeres in Arabidopsis MRE11 mutants. Plant Cell Online 14:2451-2462

Cavalier-Smith T (2010) Origin of the cell nucleus, mitosis and sex: roles of intracellular coevolution. Biol Direct 5:7

Cebolla A, Vinardell JM, Kiss E, Olah B, Roudier F, Kondorosi A, Kondorosi E (1999) The mitotic inhibitor ccs52 is required for endoreduplication and ploidy-dependent cell enlargement in plants. EMBO J 18:4476-4484

Chang L, Ma H, Xue HW (2009) Functional conservation of the meiotic genes SDS and RCK in male meiosis in the monocot rice. Cell Res 19:768-782

Che L, Tang D, Wang K, Wang M, Zhu K, Yu H, Gu M, Cheng Z (2011) OsAM1 is required for leptotene-zygotene transition in rice. Cell Res 21:654-665

Chelysheva L, Vezon D, Belcram K, Gendrot G, Grelon M (2008) The Arabidopsis BLAP75/Rmi1 homologue plays crucial roles in meiotic double-strand break repair. PLoS Genet 4:e1000309

Chen ZJ (2010) Molecular mechanisms of polyploidy and hybrid vigor. Trends Plant Sci 15:57-71

Comai L (2005) The advantages and disadvantages of being polyploid. Nat Rev Genet 6:836-846

Cools T, Iantcheva A, Weimer AK, Boens S, Takahashi N, Maes S, Van den Daele H, Van Isterdael G, Schnittger A, De Veylder L (2011) The Arabidopsis thaliana checkpoint kinase WEE1 protects against premature vascular differentiation during replication stress. Plant Cell 23:1435-1448

Cooper KF, Strich R (2011) Meiotic control of the APC/C: similarities and differences from mitosis. Cell Div 6:16

Coudreuse D, Nurse P (2010) Driving the cell cycle with a minimal CDK control network. Nature 468:1074-1079

Couteau F, Belzile F, Horlow C, Grandjean O, Vezon D, Doutriaux M-P (1999) Random chromosome segregation without meiotic arrest in both male and female meiocytes of a dmc1 mutant of Arabidopsis. Plant Cell Online 11:1623-1634

Cromer L, Heyman J, Touati S, Harashima H, Araou E, Girard C, Horlow C, Wassmann K, Schnittger A, De Veylder L, Mercier R (2012) OSD1 promotes meiotic progression via APC/C inhibition and forms a regulatory network with TDM and CYCA1;2/ TAM. PLoS Genet 8:e1002865

De Muyt A, Pereira L, Vezon D, Chelysheva L, Gendrot G, Chambon A, Laine-Choinard S, Pelletier G, Mercier R, Nogue F, Grelon M (2009) A high throughput genetic screen identifies new early meiotic recombination functions in Arabidopsis thaliana. PLoS Genet 5:e1000654

De Schutter K, Joubes J, Cools T, Verkest A, Corellou F, Babiychuk E, Van Der Schueren E, Beeckman T, Kushnir S, Inze D, De Veylder L (2007) Arabidopsis WEE1 kinase controls cell cycle arrest in response to activation of the DNA integrity checkpoint. Plant Cell 19:211-225

De Storme N, Geelen D (2013) Sexual polyploidization in plantscytological mechanisms and molecular regulation. New Phytol 198(3):670-684

d'Erfurth I, Jolivet S, Froger N, Catrice O, Novatchkova M, Mercier R (2009) Turning meiosis into mitosis. PLoS Biol 7:e1000124
d'Erfurth I, Cromer L, Jolivet S, Girard C, Horlow C, Sun Y, To JP, Berchowitz LE, Copenhaver GP, Mercier R (2010) The cyclin-A CYCA1;2/TAM is required for the meiosis I to meiosis II transition and cooperates with OSD1 for the prophase to first meiotic division transition. PLoS Genet 6:e1000989

Dirks R, van Dun K, de Snoo CB, van den Berg M, Lelivelt CL, Voermans W, Woudenberg L, de Wit JP, Reinink K, Schut JW, van der Zeeuw E, Vogelaar A, Freymark G, Gutteling EW, Keppel MN, van Drongelen P, Kieny M, Ellul P, Touraev A, Ma H, de Jong H, Wijnker E (2009) Reverse breeding: a novel breeding approach based on engineered meiosis. Plant Biotechnol J 7:837-845

Dissmeyer N, Nowack MK, Pusch S, Stals H, Inze D, Grini PE, Schnittger A (2007) T-Loop phosphorylation of Arabidopsis CDKA; 1 is required for its function and can be partially substituted by an aspartate residue. Plant Cell 19:972-985

Dissmeyer N, Weimer AK, Pusch S, De Schutter K, Kamei CL, Nowack M, Novak B, Duan GL, Zhu YG, De Veylder L, Schnittger A (2009) Control of cell proliferation, organ growth, and DNA damage response operate independently of dephosphorylation of the Arabidopsis Cdk1 homolog CDKA;1. Plant Cell 21:3641-3654

Dissmeyer N, Weimer AK, De Veylder L, Novak B, Schnittger A (2010) The regulatory network of cell-cycle progression is fundamentally different in plants versus yeast or metazoans. Plant Signal Behav 5:1613-1618

Doutriaux MP, Couteau F, Bergounioux C, White C (1998) Isolation and characterisation of the RAD51 and DMC1 homologs from Arabidopsis thaliana. Mol Gen Genet 257:283-291

Edlinger B, Schlogelhofer P (2011) Have a break: determinants of meiotic DNA double strand break (DSB) formation and processing in plants. J Exp Bot 62:1545-1563

Egel R (1971) Physiological aspects of conjugation in fission yeast. Planta 98:89-96

Esposito MS, Esposito RE (1969) The genetic control of sporulation in Saccharomyces. I. The isolation of temperature-sensitive sporulation-deficient mutants. Genetics 61:79-89

Fisher D, Krasinska L, Coudreuse D, Novak B (2012) Phosphorylation network dynamics in the control of cell cycle transitions. J Cell Sci 125:4703-4711

Foley E, Sprenger F (2001) The cyclin-dependent kinase inhibitor Roughex is involved in mitotic exit in Drosophila. Curr Biol 11:151-160

Fung TK, Yam CH, Poon RY (2005) The N-terminal regulatory domain of cyclin A contains redundant ubiquitination targeting sequences and acceptor sites. Cell Cycle 4:1411-1420

Gallego ME, Jeanneau M, Granier F, Bouchez D, Bechtold N, White CI (2001) Disruption of the Arabidopsis RAD50 gene leads to plant sterility and MMS sensitivity. Plant J 25:31-41

Garcia-Aguilar M, Michaud C, Leblanc O, Grimanelli D (2010) Inactivation of a DNA methylation pathway in maize reproductive organs results in apomixis-like phenotypes. Plant Cell Online 22:3249-3267

Gartner A, Milstein S, Ahmed S, Hodgkin J, Hengartner MO (2000) A conserved checkpoint pathway mediates DNA DamageInduced apoptosis and cell cycle arrest in $<\mathrm{i}>\mathrm{C}$. elegans. Mol Cell 5:435-443

Ghabrial A, Schüpbach T (1999) Activation of a meiotic checkpoint regulates translation of Gurken during Drosophila oogenesis. Nat Cell Biol 1:354-357

Glotzer M, Murray AW, Kirschner MW (1991) Cyclin is degraded by the ubiquitin pathway. Nature 349:132-138

Glover J, Grelon M, Craig S, Chaudhury A, Dennis E (1998) Cloning and characterization of MS5 from Arabidopsis: a gene critical in male meiosis. Plant J 15:345-356

Goldberg RB, Beals TP, Sanders PM (1993) Anther development: basic principles and practical applications. Plant Cell 5:1217 
Golubovskaya I, Grebennikova ZK, Avalkina NA, Sheridan WF (1993) The role of the ameiotic1 gene in the initiation of meiosis and in subsequent meiotic events in maize. Genetics 135:1151

Gönczy P, Thomas BJ, DiNardo S (1994) i>roughex is a dosedependent regulator of the second meiotic division during Drosophila spermatogenesis. Cell 77:1015-1025

Gonzalez N, Hernould M, Delmas F, Gevaudant F, Duffe P, Causse M, Mouras A, Chevalier C (2004) Molecular characterization of a WEE1 gene homologue in tomato (Lycopersicon esculentum Mill.). Plant Mol Biol 56:849-861

Greer E, Martin AC, Pendle A, Colas I, Jones AM, Moore G, Shaw P (2012) The Ph1 locus suppresses Cdk2-type activity during premeiosis and meiosis in wheat. Plant Cell 24:152-162

Griffiths S, Sharp R, Foote TN, Bertin I, Wanous M, Reader S, Colas I, Moore G (2006) Molecular characterization of Ph1 as a major chromosome pairing locus in polyploid wheat. Nature 439:749-752

Gross SD, Schwab MS, Taieb FE, Lewellyn AL, Qian YW, Maller JL (2000) The critical role of the MAP kinase pathway in meiosis II in Xenopus oocytes is mediated by p90(Rsk). Curr Biol 10:430-438

Groß-Hardt R, Lenhard M, Laux T (2002) WUSCHEL signaling functions in interregional communication during Arabidopsis ovule development. Genes Dev 16:1129-1138

Grossniklaus U, Schneitz K (1998) The molecular and genetic basis of ovule and megagametophyte development. Semin Cell Dev Biol 9:227-238

Harashima H, Schnittger A (2012) Robust reconstitution of active cell-cycle control complexes from co-expressed proteins in bacteria. Plant Methods 8:23

Harashima H, Dissmeyer N, Schnittger A (2013) Cell cycle control across the eukaryotic kingdom. Trends Cell Biol 23(7):345-356

Hartung F, Puchta H (1999) Isolation of the complete cDNA of the Mre11 homologue of Arabidopsis (Accession No. AJ243822) indicates conservation of DNA recombination mechanisms between plants and other eukaryotes. Plant Physiol 121:312

Hartung F, Wurz-Wildersinn R, Fuchs J, Schubert I, Suer S, Puchta H (2007) The catalytically active tyrosine residues of both SPO111 and SPO11-2 are required for meiotic double-strand break induction in Arabidopsis. Plant Cell 19:3090-3099

Hartung F, Suer S, Knoll A, Wurz-Wildersinn R, Puchta H (2008) Topoisomerase 3alpha and RMI1 suppress somatic crossovers and are essential for resolution of meiotic recombination intermediates in Arabidopsis thaliana. PLoS Genet 4:e1000285

Heyman J, De Veylder L (2012) The anaphase-promoting complex/ cyclosome in control of plant development. Mol plant 5:1182-1194

Hochegger H, Klotzbucher A, Kirk J, Howell M, le Guellec K, Fletcher K, Duncan T, Sohail M, Hunt T (2001) New B-type cyclin synthesis is required between meiosis I and II during Xenopus oocyte maturation. Development 128:3795-3807

Holm PB (1977) The premeiotic DNA replication of euchromatin and heterochromatin in Lilium longiflorum (Thunb.). Carlsberg Res Commun 42:249-281

Ito T, Nagata N, Yoshiba Y, Ohme-Takagi M, Ma H, Shinozaki K (2007) Arabidopsis MALE STERILITY1 encodes a PHD-type transcription factor and regulates pollen and tapetum development. Plant Cell Online 19:3549-3562

Iwata E, Ikeda S, Matsunaga S, Kurata M, Yoshioka Y, Criqui MC, Genschik P, Ito M (2011) GIGAS CELL1, a novel negative regulator of the anaphase-promoting complex/cyclosome, is required for proper mitotic progression and cell fate determination in Arabidopsis. Plant Cell 23:4382-4393

Izawa D, Goto M, Yamashita A, Yamano H, Yamamoto M (2005) Fission yeast Mes1p ensures the onset of meiosis II by blocking degradation of cyclin Cdc13p. Nature 434:529-533
Jia L, Kim S, Yu H (2013) Tracking spindle checkpoint signals from kinetochores to APC/C. Trends Biochem Sci 38(6):302-311

Kevei Z, Baloban M, Da Ines O, Tiricz H, Kroll A, Regulski K, Mergaert P, Kondorosi E (2011) Conserved CDC20 cell cycle functions are carried out by two of the five isoforms in Arabidopsis thaliana. PLoS ONE 6:e20618

Kitajima TS, Kawashima SA, Watanabe Y (2004) The conserved kinetochore protein shugoshin protects centromeric cohesion during meiosis. Nature 427:510-517

Knight E, Greer E, Draeger T, Thole V, Reader S, Shaw P, Moore G (2010) Inducing chromosome pairing through premature condensation: analysis of wheat interspecific hybrids. Funct Integr Genomics 10:603-608

Kohler C, Mittelsten Scheid O, Erilova A (2010) The impact of the triploid block on the origin and evolution of polyploid plants. Trends Genet 26:142-148

Lara-Gonzalez P, Westhorpe FG, Taylor SS (2012) The spindle assembly checkpoint. Curr Biol 22:R966-R980

LeMaire-Adkins R, Radke K, Hunt PA (1997) Lack of checkpoint control at the metaphase/anaphase transition: a mechanism of meiotic nondisjunction in mammalian females. J Cell Biol 139:1611-1619

Leu J-Y, Roeder GS (1999) The pachytene checkpoint in S. cerevisiae depends on Swe1-mediated phosphorylation of the cyclindependent kinase Cdc28. Mol Cell 4:805

Li W, Chen C, Markmann-Mulisch U, Timofejeva L, Schmelzer E, Ma H, Reiss B (2004) The Arabidopsis AtRAD51 gene is dispensable for vegetative development but required for meiosis. Proc Natl Acad Sci USA 101:10596-10601

Lieber D, Lora J, Schrempp S, Lenhard M, Laux T (2011) $\mathrm{i}>$ Arabidopsis WIH1 and $<\mathrm{i}>\mathrm{WIH} 2$ genes act in the transition from somatic to reproductive cell fate. Curr Biol 21:1009-1017

Lydall D, Nikolsky Y, Bishop DK, Weinert T (1996) A meiotic recombination checkpoint controlled by mitotic checkpoint genes. Nature 383(6603):840-843

Ma H (2006) A molecular portrait of Arabidopsis meiosis. In: Somerville CR, Meyerowitz EM (eds) The Arabidopsis book. American Society of Plant Biologists, Rockville, MD

Magnard JL, Yang M, Chen YC, Leary M, McCormick S (2001) The Arabidopsis gene tardy asynchronous meiosis is required for the normal pace and synchrony of cell division during male meiosis. Plant Physiol 127:1157-1166

Marimuthu MP, Jolivet S, Ravi M, Pereira L, Davda JN, Cromer L, Wang L, Nogue F, Chan SW, Siddiqi I, Mercier R (2011) Synthetic clonal reproduction through seeds. Science 331:876

Marrocco K, Bergdoll M, Achard P, Criqui MC, Genschik P (2010) Selective proteolysis sets the tempo of the cell cycle. Curr Opin Plant Biol 13:631-639

Menges M, de Jager SM, Gruissem W, Murray JA (2005) Global analysis of the core cell cycle regulators of Arabidopsis identifies novel genes, reveals multiple and highly specific profiles of expression and provides a coherent model for plant cell cycle control. Plant J 41:546-566

Mercier R, Grelon M (2008) Meiosis in plants: 10 years of gene discovery. Cytogenet Genome Res 120:281-290

Mercier R, Vezon D, Bullier E, Motamayor JC, Sellier A, Lefevre F, Pelletier G, Horlow C (2001) SWITCH1 (SWI1): a novel protein required for the establishment of sister chromatid cohesion and for bivalent formation at meiosis. Genes Dev 15:1859-1871

Morgan DO (1997) Cyclin-dependent kinases: engines, clocks, and microprocessors. Annu Rev Cell Dev Biol 13:261-291

Motamayor JC, Vezon D, Bajon C, Sauvanet A, Grandjean O, Marchand M, Bechtold N, Pelletier G, Horlow C (2000) Switch (swi1), an Arabidopsis thaliana mutant affected in the female meiotic switch. Sex Plant Reprod 12:209-218

Nasmyth K (1996) At the heart of the budding yeast cell cycle. Trends Genet 12:405-412 
Nonomura K, Morohoshi A, Nakano M, Eiguchi M, Miyao A, Hirochika H, Kurata N (2007) A germ cell specific gene of the ARGONAUTE family is essential for the progression of premeiotic mitosis and meiosis during sporogenesis in rice. Plant Cell 19:2583-2594

Nonomura K, Eiguchi M, Nakano M, Takashima K, Komeda N, Fukuchi S, Miyazaki S, Miyao A, Hirochika H, Kurata N (2011) A novel RNA-recognition-motif protein is required for premeiotic G1/S phase transition in rice (Oryza sativa L.). PLoS Genet 7:e1001265

Nowack MK, Harashima H, Dissmeyer N, Zhao X, Bouyer D, Weimer AK, De Winter F, Yang F, Schnittger A (2012) Genetic framework of cyclin-dependent kinase function in Arabidopsis. Dev Cell 22:1030-1040

Odorisio T, Rodriguez TA, Evans EP, Clarke AR, Burgoyne PS (1998) The meiotic checkpoint monitoring sypapsis eliminates spermatocytes via p53-independent apoptosis. Nat Genet 18:257-261

Olmedo-Monfil V, Duran-Figueroa N, Arteaga-Vazquez M, DemesaArevalo E, Autran D, Grimanelli D, Slotkin RK, Martienssen RA, Vielle-Calzada JP (2010) Control of female gamete formation by a small RNA pathway in Arabidopsis. Nature 464:628-632

Osman K, Higgins JD, Sanchez-Moran E, Armstrong SJ, Franklin FC (2011) Pathways to meiotic recombination in Arabidopsis thaliana. New Phytol 190:523-544

Otto SP (2007) The evolutionary consequences of polyploidy. Cell 131:452-462

Pagliuca FW, Collins MO, Lichawska A, Zegerman P, Choudhary JS, Pines J (2011) Quantitative proteomics reveals the basis for the biochemical specificity of the cell-cycle machinery. Mol Cell 43:406-417

Pawlowski WP, Wang CJ, Golubovskaya IN, Szymaniak JM, Shi L, Hamant O, Zhu T, Harper L, Sheridan WF, Cande WZ (2009) Maize AMEIOTIC1 is essential for multiple early meiotic processes and likely required for the initiation of meiosis. Proc Natl Acad Sci USA 106:3603-3608

Pesin JA, Orr-Weaver TL (2008) Regulation of APC/C activators in mitosis and meiosis. Annu Rev Cell Dev Biol 24:475-499

Peters JM (2006) The anaphase promoting complex/cyclosome: a machine designed to destroy. Nat Rev Mol Cell Biol 7:644-656

Pines J (1995) Cyclins and cyclin-dependent kinases: a biochemical view. Biochem J 308:697-711

Pittman DL, Cobb J, Schimenti KJ, Wilson LA, Cooper DM, Brignull E, Handel MA, Schimenti JC (1998) Meiotic prophase arrest with failure of chromosome synapsis in mice deficient for Dmc1, a germline-specific RecA homolog. Mol Cell 1:697-705

Ponticelli AS, Smith GR (1989) Meiotic recombination-deficient mutants of Schizosaccharomyces pombe. Genetics 123:45-54

Puizina J, Siroky J, Mokros P, Schweizer D, Riha K (2004) Mre11 deficiency in Arabidopsis is associated with chromosomal instability in somatic cells and Spo11-dependent genome fragmentation during meiosis. Plant Cell Online 16:1968-1978

Ramachandran V, Matzkies M, Dienemann A, Sprenger F (2007) Cyclin A degradation employs preferentially used lysines and a cyclin box function other than Cdk1 binding. Cell Cycle 6:171-181

Ravi M, Chan SW (2010) Haploid plants produced by centromeremediated genome elimination. Nature 464:615-618

Reddy TV, Kaur J, Agashe B, Sundaresan V, Siddiqi I (2003) The DUET gene is necessary for chromosome organization and progression during male meiosis in Arabidopsis and encodes a PHD finger protein. Development 130:5975-5987

Riehs N, Akimcheva S, Puizina J, Bulankova P, Idol RA, Siroky J, Schleiffer A, Schweizer D, Shippen DE, Riha K (2008) Arabidopsis SMG7 protein is required for exit from meiosis. J Cell Sci 121:2208-2216
Riehs-Kearnan N, Gloggnitzer J, Dekrout B, Jonak C, Riha K (2012) Aberrant growth and lethality of Arabidopsis deficient in nonsense-mediated RNA decay factors is caused by autoimmune-like response. Nucleic Acids Res 40:5615-5624

Riley R, Chapman V (1958) Genetic control of the cytologically diploid behaviour of hexaploid wheat. Nature 182:713-715

Rockmill B, Sym M, Scherthan H, Roeder GS (1995) Roles for two RecA homologs in promoting meiotic chromosome synapsis. Genes Dev 9:2684-2695

Roeder GS, Bailis JM (2000) The pachytene checkpoint. Trends Genet TIG 16:395

Romanienko PJ, Camerini-Otero RD (2000) The mouse Spol1 gene is required for meiotic chromosome synapsis. Mol Cell 6:975-987

Ross KJ, Fransz P, Armstrong SJ, Vizir I, Mulligan B, Franklin FC, Jones GH (1997) Cytological characterization of four meiotic mutants of Arabidopsis isolated from T-DNA-transformed lines. Chromosome Res 5:551-559

Sanders PM, Bui AQ, Weterings K, McIntire KN, Hsu Y-C, Lee PY, Truong MT, Beals TP, Goldberg RB (1999) Anther developmental defects in Arabidopsis thaliana male-sterile mutants. Sex Plant Reprod 11:297-322

Shuster EO, Byers B (1989) Pachytene arrest and other meiotic effects of the start mutations in Saccharomyces cerevisiae. Genetics 123:29-43

Siddiqi I, Ganesh G, Grossniklaus U, Subbiah V (2000) The dyad gene is required for progression through female meiosis in Arabidopsis. Development 127:197-207

Singh M, Goel S, Meeley RB, Dantec C, Parrinello H, Michaud C, Leblanc O, Grimanelli D (2011) Production of viable gametes without meiosis in maize deficient for an ARGONAUTE protein. Plant Cell 23:443-458

Sorrell DA, Marchbank A, McMahon K, Dickinson JR, Rogers HJ, Francis D (2002) A WEE1 homologue from Arabidopsis thaliana. Planta 215:518-522

Stern B, Nurse P (1996) A quantitative model for the cdc2 control of $S$ phase and mitosis in fission yeast. Trends Genet 12:345-350

Sun Y, Dilkes BP, Zhang C, Dante RA, Carneiro NP, Lowe KS, Jung R, Gordon-Kamm WJ, Larkins BA (1999) Characterization of maize (Zea mays L.) Wee1 and its activity in developing endosperm. Proc Natl Acad Sci USA 96:4180-4415

Takanami T, Sato S, Ishihara T, Katsura I, Takahashi H, Higashitani A (1998) Characterization of a Caenorhabditis elegans recA-like gene Ce-rdh-1 involved in meiotic recombination. DNA Res 5:373-377

Uanschou C, Siwiec T, Pedrosa-Harand A, Kerzendorfer C, SanchezMoran E, Novatchkova M, Akimcheva S, Woglar A, Klein F, Schlögelhofer P (2007) A novel plant gene essential for meiosis is related to the human CtIP and the yeast COM1/SAE2 gene. EMBO J 26:5061-5070

Vandepoele K, Raes J, De Veylder L, Rouze P, Rombauts S, Inze D (2002) Genome-wide analysis of core cell cycle genes in Arabidopsis. Plant Cell 14:903-916

Vanneste S, Coppens F, Lee E, Donner TJ, Xie Z, Van Isterdael G, Dhondt S, De Winter F, De Rybel B, Vuylsteke M, De Veylder L, Friml J, Inze D, Grotewold E, Scarpella E, Sack F, Beemster GT, Beeckman T (2011) Developmental regulation of CYCA2s contributes to tissue-specific proliferation in Arabidopsis. EMBO J 30:3430-3441

Wang G, Kong H, Sun Y, Zhang X, Zhang W, Altman N, DePamphilis CW, Ma H (2004a) Genome-wide analysis of the cyclin family in Arabidopsis and comparative phylogenetic analysis of plant cyclin-like proteins. Plant Physiol 135:1084-1099

Wang Y, Magnard JL, McCormick S, Yang M (2004b) Progression through meiosis I and meiosis II in Arabidopsis anthers is regulated by an A-type cyclin predominately expressed in prophase I. Plant Physiol 136:4127-4135 
Wijnker E, van Dun K, de Snoo CB, Lelivelt CLC, Keurentjes JJB, Naharudin NS, Ravi M, Chan SWL, de Jong H, Dirks R (2012) Reverse breeding in Arabidopsis thaliana generates homozygous parental lines from a heterozygous plant. Nat Genet 44(4):467-470

Wilkins AS, Holliday R (2009) The evolution of meiosis from mitosis. Genetics 181:3-12

Wilson ZA, Morroll SM, Dawson J, Swarup R, Tighe PJ (2001) The Arabidopsis MALE STERILITY1 (MS1) gene is a transcriptional regulator of male gametogenesis, with homology to the PHD-finger family of transcription factors. Plant J 28:27-39

Wohlbold L, Fisher RP (2009) Behind the wheel $<i>$ and under the hood: functions of cyclin-dependent kinases in response to DNA damage. DNA Repair 8:1018-1024

Woods LM, Hodges CA, Baart E, Baker SM, Liskay M, Hunt PA (1999) Chromosomal influence on meiotic spindle assembly: abnormal meiosis I in female Mlh1 mutant mice. J Cell Biol 145:1395-1406

Wylie C (1999) Germ cells. Cell 96:165-174
Xie Z, Lee E, Lucas JR, Morohashi K, Li D, Murray JA, Sack FD, Grotewold E (2010) Regulation of cell proliferation in the stomatal lineage by the Arabidopsis MYB FOUR LIPS via direct targeting of core cell cycle genes. Plant Cell 22:2306-2321

Yang WC, Ye D, Xu J, Sundaresan V (1999) The SPOROCYTELESS gene of Arabidopsis is required for initiation of sporogenesis and encodes a novel nuclear protein. Genes Dev 13:2108-2117

Yang X, Makaroff CA, Ma H (2003) The Arabidopsis MALE MEIOCYTE DEATH1 gene encodes a PHD-finger protein that is required for male meiosis. Plant Cell Online 15:1281-1295

Yoshida K, Kondoh G, Matsuda Y, Habu T, Nishimune Y, Morita T (1998) The mouse RecA-like gene Dmc1 is required for homologous chromosome synapsis during meiosis. Mol Cell $1: 707-718$

Zhao X, Harashima H, Dissmeyer N, Pusch S, Weimer AK, Bramsiepe J, Bouyer D, Rademacher S, Nowack MK, Novak B, Sprunck S, Schnittger A (2012) A general G1/S phase cellcycle control module in the flowering plant Arabidopsis thaliana. PLoS Genet 8:e1002847 